\title{
Evapotranspiration with Plantains and the Effect of Frequency of Irrigation on Yields ${ }^{1,2}$
}

\author{
Fernando Abruña, José Vicente-Chandler, Héber Irizarry, and \\ Servando Silva ${ }^{3}$ \\ ABSTRACT \\ Evapotranspiration by plantains growing on a heavy Mabí soil (Vertic \\ Eutropepts) averaged 2.9, 2.5 and $2.4 \mathrm{~mm}$ daily. Yields were 15,695, 22,215, \\ and $24,225 \mathrm{~kg} /$ ha when irrigation was applied whenever available soil mois- \\ ture was depleted by 20,40 and $60 \%$, respectively. Overall evapotranspiration \\ for all treatments averaged $68.9 \%$ of open pan evaporation. Evapotranspira- \\ tion in the most frequently irrigated plots averaged $80 \%$ and $61 \%$ of open \\ pan evaporation during the period of rapid vegetative growth and during the \\ period from flowering to harvest, respectively.
}

\section{INTRODUCTION}

Although plantains (Musa acuminata $\times$ M. balbisiana) are a major food crop of the tropics (about 20 million metric tons are marketed yearly), there is little research information available on their cultural requirements. Plantains have been grown successfully in areas with annual rainfall ranging from 1,500 to $3,000, \mathrm{~mm}$ and they can tolerate several months of drought during some stages of development.

Although Ghavami ${ }^{4}$ and Arscott et al., 5 among others, have studied the irrigation of bananas (Musa acuminata) the authors have found no reference to such studies with plantains. Information on evapotranspiration can help to determine the adaptation of plantains to different areas and their irrigation requirements.

The main climatic factors affecting evapotranspiration are solar energy, relative humidity and air movement. Evaporation from an open pan constitutes a simple measurement of the integrated effect of these climatic factors and generally correlates with evapotranspiration by crops. It can therefore serve as a basis for transferring information on evapotranspiration by a crop from one area to another.

'Manuscript submitted to the Editorial Board on December 11, 1978.

${ }^{2}$ Research conducted cooperatively between Agricultural Research Science and Education Administration, USDA and the College of Agricultural Sciences, Mayagüez Campus, University of Puerto Rico,

${ }^{3}$ Soil Scientist, Location Leader-Soil Scientist, Research Horticulturist, and Technician Aid, respectively, Agricultural Research, Science and Education Administration, USDA, Río Piedras, P. R.

${ }^{4}$ Ghavami, M., Water need of banana plants, Transactions of the ASAE 16(3): 498-600, 1973 .

${ }^{5}$ Arscott, T. S., Bhangoo, M. S., and Karon, M. Y., Irrigation Investigation of the Giant Cavendish Banana, Tropical Agriculture 42: 139-144, 1965. 
The study reported here determined the effect of three frequencies of irrigation on yields and evapotranspiration of intensively managed plantains. The relation between evapotranspiration and open pan evaporation was also examined.

\section{MATERIALS AND METHODS}

The experiment was carried out at the Gurabo Substation, which is at an elevation of about $50 \mathrm{~m}$. Annual rainfall is about $1,500 \mathrm{~mm}$; generally there is a dry season in winter, and there are heavy rains in the fall. Average annual temperature is about $25^{\circ} \mathrm{C}$, with a mean monthly variation of about $5^{\circ} \mathrm{C}$.

The soil is a nearly level heavy Mabí clay (Vertic Eutropepts) with restricted internal drainage, a bulk density of 1.5 , a $\mathrm{pH}$ of $5.8,3.6 \%$ of organic matter, 26 meq of exchange capacity and 17 meq of exchangeable bases/100 g of soil.

Daily evaporation and rainfall were determined with a standard open pan and a rain gauge. Maximum and minimum daily temperatures and daily wind movement were recorded.

The experimental area was surrounded by fields of intensively managed, well irrigated plantains that served as effective border areas. The experimental plots were planted at $2 \times 2 \mathrm{~m}$ with a high yielding Maricongo cultivar fertilized with $2,000 \mathrm{~kg}$ of $10-5-20 / \mathrm{ha} / \mathrm{yr}$ divided into three equal applications. The suckers used for planting were peeled and dipped in a nematicide-insecticide solution. These pesticides were applied in granular form every $4 \mathrm{mo}$. The plants were not sprayed because the incidence of Sigatoka (Cercospora musae) leaf spot was low. The soil was kept free of weeds by periodic applications of herbicides until about 6 mo after planting, when the dense shade of the plants prevented weed growth. The experiment was planted in April 1976 and the bunches were harvested from April to June 1977.

The twelve $10 \times 10$ plots used in the experiment were leveled and surrounded by earth dikes so that they could be irrigated without run-off or movement of water from one plot to another. The plots were irrigated by flooding with about $15 \mathrm{~cm}$ of water. Any water remaining on the surface $12 \mathrm{~h}$ later was removed by making a cut in the dikes.

The irrigation treatments, started 4 mo after planting when the plants were about $1.5 \mathrm{~m}$ high, consisted of irrigating when about 20,40 , and $60 \%$ of the available moisture in the soil had been depleted. Evapotranspiration was estimated to be $75 \%$ of open pan evaporation. All irrigation treatments were replicated four times in a randomized block design.

Undisturbed soil cores were taken at $15-\mathrm{cm}$ intervals in all plots to a depth of $45 \mathrm{~cm}$. Bulk density, total pore space, and percent moisture unavailable to plants were determined by standard procedures. Field 
capacity of the soil was ascertained by determining the moisture content of 10 soil samples taken in each plot at $15-\mathrm{cm}$ intervals to a depth of 45 $\mathrm{cm} 3$ days after thoroughly wetting the soil by flooding. Soil moisture available to the plants was considered to be field capacity minus unavailable moisture.

The upper $45 \mathrm{~cm}$ of this soil are considered the zone from which moisture can be extracted because plantain roots are confined to this layer, as shown by the following data taken from the work of Irizarry and Silva ${ }^{6}$ conducted on this soil.

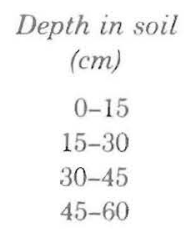

Plantain roots
$\left(\mathrm{cm} / 1,000 \mathrm{~cm}^{3}\right.$ of soil)
95
18
6
0

Evapotranspiration over the various periods between irrigations was calculated as follows: moisture in the soil at field capacity minus the moisture in the soil before irrigating plus the effective rainfall. Field capacity and moisture remaining in the soil before irrigation were determined by taking 10 soil samples in each plot at $15 \mathrm{~cm}$ intervals to a depth of $45 \mathrm{~cm}$. Effective rainfall was calculated from daily rainfall records in relation to the deficiency of moisture in the soil, i.e., field capcity minus the estimated evapotranspiration ( $75 \%$ of open pan evaporation). If rainfall was less than the deficiency in soil moisture, all the rain was assumed to be available for evapotranspiration. If rainfall exceeded the soil moisture deficiency, the excess was assumed to be lost by runoff or deep percolation.

Records were kept for about 8 mo from September 1976, when the irrigation treatments began, to April 1977, when all plantains had produced a bunch and a third of the crop had been harvested.

Yields of all plots were determined.

\section{RESULTS AND DISCUSSIONS}

Table 1. shows that the root zone $(0-45 \mathrm{cms})$ of this Mabi soil had an average bulk density of 1.5 and total pore space of $46.9 \%$. Soil moisture at field capacity averaged $26.3 \%$ with $14.9 \%$ unavailable to plants, leaving an available soil moisture content of $11.4 \%$ by weight, equivalent to 26.1 $\mathrm{mm}$ for each $15 \mathrm{~cm}$ of soil or a total of $78.3 \mathrm{~mm}$ of available water in the $0-45 \mathrm{~cm}$ root zone.

\footnotetext{
${ }^{6}$ Irizarry, H., and Silva, S., Studies on the root systems of plantain. Submitted for publication, J. Agri. Univ. P.R.
} 
During the experiment, total rainfall $(834.2 \mathrm{~mm})$ was little less than total open pan evaporation $(926.8 \mathrm{~mm})$, but it was unevenly distributed, ranging from $18 \mathrm{~mm}$ in February to $320.5 \mathrm{~mm}$ in October, resulting in definite periods of moisture deficiency (table 2). Open pan evaporation ranged from about $90 \mathrm{~mm}$ in December and January to about $140 \mathrm{~mm}$ in March and April. Kilometers of wind per month ranged from 965 in October to over 2,200 km in March and April. Maximum and minimum

TABLE 1.-Some physical characteristics of the Mabi clay soil at the experimental site

\begin{tabular}{ccccccc}
\hline Depth & $\begin{array}{c}\text { Bulk } \\
\text { density }\end{array}$ & $\begin{array}{c}\text { Total } \\
\text { pore space }\end{array}$ & $\begin{array}{c}\text { Field } \\
\text { capacity }{ }^{1}\end{array}$ & $\begin{array}{c}\text { Soil } \\
\text { moisture } \\
\text { unavail- } \\
\text { able to } \\
\text { plants }\end{array}$ & $\begin{array}{c}\text { Available } \\
\text { moisture }\end{array}$ & $\begin{array}{c}\text { Available } \\
\text { water }^{3}\end{array}$ \\
\hline$C m$ & 1.5 & 50.3 & 25.6 & 14.9 & 10.7 & 23.4 \\
$0-5$ & 1.6 & 44.7 & 26.4 & 15.5 & 10.9 & 25.5 \\
$15-30$ & 1.5 & 45.6 & 26.9 & 14.2 & 12.7 & 29.4 \\
$30-45$ & 1.5 & 46.9 & 26.3 & 14.9 & 11.4 & 26.1 \\
Average & & $\%$ & $\%$ & $\%$ & $\%$ & \%m \\
\hline
\end{tabular}

${ }^{1}$ Moisture retained in the soil 3 days after thorough wetting.

${ }^{2}$ Field capacity minus unavailable moisture.

${ }^{3} \%$ available moisture by weight $\times$ bulk density $\times 15 \mathrm{~cm}$.

TABLE 2.-Climatic data taken at the experimental site during the course of the experiment

\begin{tabular}{|c|c|c|c|c|c|c|}
\hline \multirow{2}{*}{ Month } & \multirow{2}{*}{ Rainfall } & \multirow{2}{*}{$\begin{array}{l}\text { Oven pan } \\
\text { evaporation }\end{array}$} & \multirow{2}{*}{ Wind } & \multicolumn{3}{|c|}{ Air temperatures ${ }^{\circ} \mathrm{C}$} \\
\hline & & & & Max. & Min. & Ave. \\
\hline & $M m$ & $M m$ & $\mathrm{Km} / \mathrm{mo}$ & & & \\
\hline September/76 & 173.2 & 127.0 & 1,321 & 31.5 & 20.9 & 26.2 \\
\hline October & 320.5 & 114.6 & 965 & 30.5 & 20.9 & 25.7 \\
\hline November & 50.3 & 113.0 & 1,442 & 29.7 & 19.6 & 24.6 \\
\hline December & 61.5 & 89.2 & 1,290 & 28.9 & 17.3 & 23.2 \\
\hline January $/ 77$ & 84.8 & 91.2 & 1,205 & 28.6 & 16.8 & 22.7 \\
\hline February & 18.0 & 112.3 & 1,792 & 29.3 & 16.9 & 23.1 \\
\hline March & 36.3 & 141.2 & 2,214 & 30.0 & 16.5 & 23.3 \\
\hline April & 89.4 & 138.4 & 2,209 & 29.7 & 17.8 & 23.7 \\
\hline Total & 834.2 & 926.8 & 12,438 & - & - & - \\
\hline
\end{tabular}

temperature ranged from $28.6^{\circ} \mathrm{C}$ in January to $31.5^{\circ} \mathrm{C}$ in September and from $16.5^{\circ} \mathrm{C}$ in March to 20.9 in September and October, respectively. Average monthly temperature ranged from $22.7^{\circ} \mathrm{C}$ in January to $26.2^{\circ} \mathrm{C}$ in September.

The following tabulation shows that irrigation when available soil mositure was depleted by $20 \%$ resulted in significantly lower plantain yields than those when the plantains were irrigated after 40 or $60 \%$ of the available moisture had been depleted. 


$\begin{array}{cc}\begin{array}{c}\text { Irrigated when } \\ \text { available soil }\end{array} & \text { Plantain } \\ \text { moisture was } & \text { Yields }(\mathrm{kg} / \mathrm{ha} \text { ) } \\ \text { reduced by: } & \\ 20 \% & 15,695 \mathrm{~b} \\ 40 \% & 22,215 \mathrm{a} \\ 60 \% & 24,225 \mathrm{a}\end{array}$

The decrease in plantain yields caused by too frequent irrigations was probably the result of excessive moisture in the lower level of this heavy soil during most of the time. Irizarry et al. ${ }^{7}$ found that plantain yields increased with each drop in the soil water tables as shown in the following tabulation:

$\begin{array}{cc}\text { Depth of water } & \text { Plantain yields } \\ \text { table }(\mathrm{cm}) & (\mathrm{kg} / \mathrm{ha}) \\ \text { I2 } & 5,650 \\ 24 & 25,550 \\ 36 & 37,800\end{array}$

The following tabulation shows that overall average daily evapotranspiration with plantain decreased with increasing intervals between irrigation:

Irrigated when available
soil moisture
depleted by

$20 \%$

$40 \%$

$60 \%$

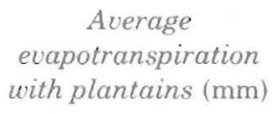

2.9

2.5

2.4
Percentage of
open pan
evaporation

79

65

59

Fuhriman and Smith ${ }^{8}$ in large scale field trials on the south coast of Puerto Rico found that sugarcane used an average of $4 \mathrm{~mm}$ of water daily. Using the overall average $(67 \%)$ of open pan evaporation for the three irrigation levels tested with plantains at Gurabo, and applying this average to the open pan evaporation for the south coast $(5.7 \mathrm{~mm}$ ) reported by Fuhriman and Smith, we can conclude that plantains on the southern coast would probably use an average of $3.8 \mathrm{~mm}$ of moisture daily, which is very similar to the values they reported for sugarcane in that area.

Figure 1 shows evapotranspiration over about 8 months with plantains irrigated whenever available soil moisture was depleted by about $20 \%$. Evapotranspiration followed rather closely open pan evaporation during

'Irizarry, H., Silva, S., and Vicente-Chandler, J., Effect of water table level on yields and root system of plantains. J. Agri. Univ. P.R. 64 (1): 1980.

${ }^{8}$ Fuhriman, D. K., and Smith, R. M., 1951, Conservation and consumptive use of water with sugarcane on the south coastal area of Puerto Rico, J. Agri. Univ. P.R., 35(1) 1-47. 
the first six periods which started 4 months after planting, when the plantains had covered most of the ground and were growing rapidly. Evapotranspiration averaged $80 \%$ of open pan evaporation during this period.

Open pan evaporation increased sharply during the second six periods but evapotranspiration with plantains did not follow this increase, averaging only $61 \%$ of open pan evaporation. Almost all the plantains flowered at the beginning of this period, after which they ceased to produce new leaves and the old ones deteriorated rapidly, reducing the foliar area. This was probably accompanied by a reduction in the extent and activity

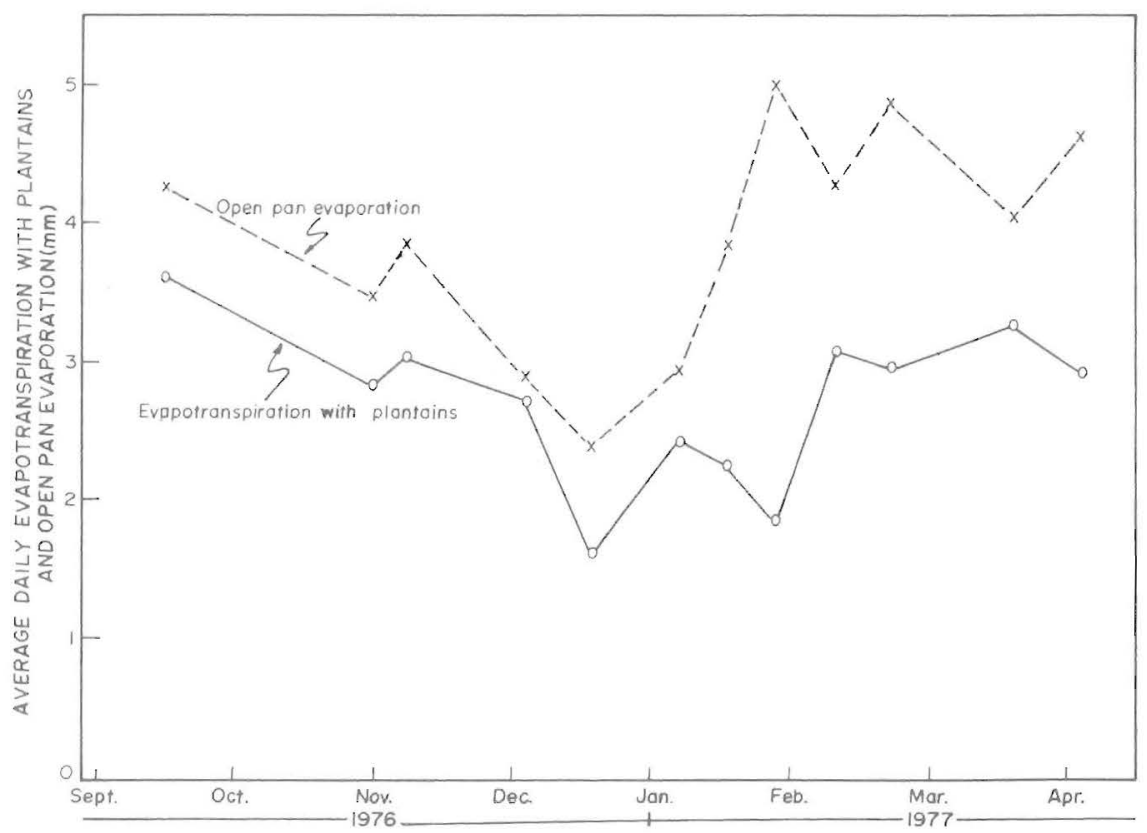

Fig. 1.-Evapotranspiration with frequently irrigated plantains and open pan evaporation starting 4 months after planting and ending at start of harvest.

of the root system. The physiological activity of plantains also probably decreases after flowering. These factors probably prevented an increase in evapotranspiration with the plantains commensurate with the increase in open pan evaporation.

Similarly, with plantains irrigated whenever $40 \%$ of the available moisture in the soil was depleted, evapotranspiration during the initial period of rapid vegetative growth averaged $72 \%$ of open pan evaporation but averaged only $50 \%$ of open pan evaporation following flowering. There were not enough irrigation periods to make such comparisons with plantains irrigated whenever available soil moisture was depleted by $60 \%$. 
The data presented in this paper show that overirrigation can reduce plantain yields on a heavy soil if good surface drainage is not provided.

\section{RESUMEN}

El efecto del riego sobre la evapotranspiración y producción del platanero sembrado en un suelo Mabí, se determinó cada vez que la humedad edáfica disponible disminuyó 20,40 y $60 \%$.

Se obtuvieron $15,696,22,214$ y $24,224 \mathrm{~kg} /$ ha cuando se regó cada vez que el agua disponible en el suelo se reducía en 20, 40 y $60 \%$, respectivamente.

La evapotranspiración media diaria fue de 2.92, 2.54 y $2.36 \mathrm{~mm}$ cuando se regó cada vez que el agua disponible en el suelo se reducía en 20,40 y $60 \%$, respectivamente. La evapotranspiración media para los tres niveles de riego en el transcurso de unos 8 meses, fue $68 \%$ de la evaporación de un tanque de agua al descubierto.

Cuando se regó cada vez que el agua disponible en el suelo se redujo en un $20 \%$, la evapotranspiración durante el período de rápido crecimiento vegetativo alcanzó un promedio equivalente a $80 \%$ de la evaporación del tanque al descubierto. Después de la floración, sin embargo, la evapotranspiración correspondió a solo un $61 \%$ de la evaporación.

Cuando se regó cada vez que el agua disponible en el suelo se redujo en un $40 \%$, la evapotranspiración durante el período de crecimiento vegetativo rápido equivalió a un $72 \%$ de la evaporación. Después de la floración, la evapotranspiración equivalió a solo un 50\% de la evaporación. 